\title{
The Financial Viability of Solar Photovoltaic Canopies as Urban Climate Change Mitigation: An Analysis of the Potential Utilization of Public Space in Boston, Massachusetts
}

\author{
Clayton Hunter ${ }^{1}$, James G. Baldwin ${ }^{1} \&$ Michael L. Mann ${ }^{2}$ \\ ${ }^{1}$ Department of Earth and Environment, Boston University, Boston, MA, USA \\ 2 Department of Geography, George Washington University, Washington, D.C., USA \\ Correspondence: James Baldwin, Department of Earth and Environment, Boston University, 675 \\ Commonwealth Ave. Boston, MA 02215, USA. E-mail: jbaldwin@bu.edu
}

\author{
Received: March 11, 2013 Accepted: March 27, 2013 Online Published: April 11, 2013 \\ doi:10.5539/eer.v3n1p158 URL: http://dx.doi.org/10.5539/eer.v3n1p158
}

Additional support was provided by the U.S. National Science Foundation ULTRA-ex program (DEB 0948857)

\begin{abstract}
We model the electrical power generation potential, calculate the associated avoided emissions and conduct an economic valuation of a scenario of large scale photovoltaic canopy implementation in metro Boston, Massachusetts on publicly managed parking real-estate operated by the Massachusetts Bay Transit Authority. The results of this work demonstrate that 102.4 MWh of electricity may be generated by such a program which is equal to nearly $0.013 \%$ of total electricity demand in the state. Annual $\mathrm{CO}_{2}, \mathrm{NO}$ and $\mathrm{SO}_{2}$ emissions avoided in this scenario amounts to 53.7 tonnes of $\mathrm{CO}_{2}, 46.5 \mathrm{~kg}$ of $\mathrm{NO}$, and $107.1 \mathrm{~kg}$ of $\mathrm{SO}_{2}$. Despite the substantial amount of power production potential we find that such a scenario is not economically viable under current market conditions and using conventional financing mechanisms with a net present value of -1.4 Billion U.S. dollars.
\end{abstract}

Keywords: solar energy, integrated generation, net present value analysis, climate change mitigation, photovoltaic canopies

\section{Introduction}

\subsection{Background}

The United States consumes approximately 1,400 terawatt-hours (TWh) of electricity annually for residential use and 3,856 TWh in total of which the state of Massachusetts is responsible for more than 740,000 megawatt-hours (MWh) of consumption (EIA, 2012). At that level, Massachusetts emits approximately 1,702,000 pounds of Sulfur Dioxide, 740,000 pounds of Nitrogen Oxide, and 854,000,000 pounds of Carbon Dioxide every year (EIA, 2012). At the national level, approximately $40 \%$ of all carbon dioxide emissions in the U.S. can be attributed to the use of fossil fuels in the production of electricity (Jun et al., 2012). There is a general scientific consensus that the emission of these and other pollutants are significant driving forces behind climate change. Large disruptions in climate are associated with adverse effects on human health, economic stability, and food security (IPCC, 2007). With this in mind we consider the possible utilization of existing publicly owned property as a location for renewable energy production in a metropolitan area using photovoltaic canopies. In this analysis, we investigate the use of large parking facilities operated by the public transportation system for Boston, Massachusetts. In particular, we consider those parking lots serving the Massachusetts Bay Transit Authority customers. These lots were chosen because of the quality of the data (see section 2) and the fact that this land is already under public management and thus available for the use of photovoltaic canopies as part of an urban distributed generation scheme. We identify the potential for electricity generation at these sites, the economic viability of such developments and quantify the offset in $\mathrm{NO}, \mathrm{SO}_{2}$ and $\mathrm{CO}_{2}$ that this renewable electricity generation entails. We do not however quantify some other values associated with these installations, such as the benefits of network resiliency and reliability. 


\subsection{Energy Valuation and Grid Integration}

There are numerous approaches that are applied to energy valuation. These techniques may be broken down into five overarching methodological categories: stated preference techniques, revealed preference techniques, financial option theory (or portfolio analysis), emergy analysis, and other economic approaches (Menegaki, 2008). However the most common approach, and the one which provides the most clear cut results for interpretation by policy makers, is net present value (NPV) analysis. This technique permits the lifetime return and lifetime cost of a project to be considered in its entirety, thus providing useful information for those attempting to determine the best use of limited funds to maximize returns to those funds. This analysis is done by simply subtracting the net present costs of a course of action from the net present benefits, which are both calculated in current dollars (2008\$) by way of a defined social discount rate. It is this technique that we employ in our valuation of a scenario in which a large scale distributed solar energy project is undertaken. However it is useful to briefly outline some of the other valuation techniques and the insight they provide with respect to renewable energy systems.

Let us first turn to stated and revealed preference techniques which seek to interpret consumer responses and behavior, respectively. Willingness to pay methods rely upon response to changing price structure while revealed prefence methods utilize trends in consumer behavior to guage how individuals value the options available to them. Multiple studies conducted over the last few years have used these techniques to demonstrate the public's positive willingness-to-pay for energy production that is cleaner and more sustainable than current practices (see Bergmann et al., 2008; Li et al., 2009). In addition to people's willingness to pay for cleaner technology,using portfolio analysis it has been estimated that increasing renewable installations by $10 \%$ in the U.S. energy portfolio could equate to US\$29-53 billion in avoided losses due to the price volatility, market risk, and other disruptions associated with fossil fuels (Menegaki, 2008). This knowledge begs the question, if people are willing to pay for cleaner energy and there is high external cost of pollution, why is there not a greater installed capacity of renewables? Aside from the historic prescedence of large, fossil fuel-based power plants, arguably the most important part of the answer to that question the inherent challenge associated with the integration of renewables with the current grid system (Denholm \& Margolis, 2006).

Integration of renewables in the current electrical grid is often argued to be problematic because of intermittency and load following issues. Intermittency is the given variability associated with uncontrollable energy sources, such as solar and wind which cannot be guaranteed to provide a steady flow of power. Load following is the ability of an energy source to produce electricity as it is demanded. In traditional power plants, this is not an issue because electricity production is completely controlled by the plant operators who are able to increase or decrease supply as needed. In their hypothetical simulation of a large-scale PV production plant, Denholm and Margolis (2006) find that, although solar electricity could provide enough electricity to power the entire U.S. and its peak output coincides with times of largest electricity demand, a $16 \mathrm{GW}$ system installed in Texas (which would meet $11 \%$ of overall electricity demand) would not be economically viable due to the costs associated with shutting down and powering up traditional, fossil fuel-powered plants to maintain constant supply-demand matching. In a more recent study that counters this finding, Sovacool (2009) surveyed a variety of energy experts with the goal of answering: (1) What do energy experts really think about renewables in the United States? (2) To what degree are conventional baseload units reliable? and (3) Is intermittency a justifiable reason to reject renewable electricity resources? He finds that experts in the energy field are hesitant about the potential of renewables mainly because of the relative ease with which conventional power sources can be controlled. Sovacool concludes that renewable energy systems are no less reliable than conventional power plants and intermittency issues can be overcome with spatially diverse installations. It is this solution of spatially diverse installations through the use of photovoltaic canopies that we evaluate herein.

\subsection{Parking Canopies}

There have been a number of studies performed that consider the impact of areas covered by parking lots, including associated environmental and economic costs (see McPherson, 2001) and loss of ecosystem services (see Davis et al., 2010). The increase in abundance of large department stores has been cited as a reason for the disproportionate increase in area covered by parking lots (Noguera, 2007). Taking that observation into consideration, and in order to minimize detrimental effects of parking lots, researchers have encouraged city planners to be intelligent about the placement of new lots, and to ensure they are necessary (Knepper, 2007). The bulk of research has focused on the aforementioned costs and benefits associated with new parking lots, but existing lots, especially in urban areas, also provide an opportunity to use existing space without changing land use. This creates an opportunity to offset some of the negative environmental impacts associated with parking facilities. There is existing research that demonstrates parking canopies have the ability to reduce the urban heat 
island (UHI) effect [increased temperatures in urban areas, as compared to rural areas, attributable to lower urban albedo and greater waste heat generation] and suggests that parking canopies with PV installations have a greater potential to reduce parking lot pavement temperatures than either canopies without PV or shade trees (Golden et al., 2007). Similarly, PV canopies are effective at reducing energy use through the shading of buildings (Mandalaki et al., 2012) providing an added benefit to building integrated parking structures. Numerous PV canopies have already been built, such as the Chevron facility at California State University Fresno, the parking structure at University of California San Diego, the Kyocera headquarters facility in San Diego and the small scale canopy at the U.S. National Renewable Energy Laboratory in Colorado. With the surge in popularity of PV parking canopies it is worth considering the economic viability of large scale implementation in urban areas with solar energy potential.

\subsection{PV System Installation and Electricity Production Estimation}

The purpose of any solar PV installation is to maximize electricity production while minimizing system costs. To achieve these goals there are choices that need to be made between various solar PV modules, inverters, and other components (such as electricity storage and charge controllers where necessary or desired). Although some new technologies are emerging, the most commonly used PV modules are built from silicon, specifically single crystalline silicon as opposed to amorphous silicon or other polycrystalline silicon structures. There are many different brands and models of PV modules. However, there are fewer choices for inverters and the specific model is selected based on the size of the system it serves. This is also true of any other electrical components the particular system may require (Ayompe et al., 2010; MCEC, 2012). In their study of 16 installed crystalline PV systems in Europe, Ayompe et al. found that the balance of system costs were approximately equal to $54 \%$ of the PV module cost. Balance of system (BOS) cost is the cost of all components (other than the PV modules) necessary for a system to function. For example the BOS cost would include the costs of inverters, structural support and wiring as well as the cost of labor to install the system. They also found that the average installation spends approximately one percent of the total cost on annual variable costs associated with maintenance of the system. There are essentially two types of support structures for PV systems, fixed structures and mobile structures with tracking systems which can track the sun's path across the sky. The predominant installation method uses a fixed structure because moving parts in a tracking system increases the risk for structural failures and increases both initial installation costs as well as maintenance costs in addition to consuming $2-3 \%$ of the energy from the panel for the drive system (Mousazadeh et al., 2009). In order to maximize the exposure of PV modules in a fixed system installed in the northern hemisphere, the modules should be tilted facing south at an angle equal to that of the location's latitude (Ayompe et al., 2010; El-Sebaii et al., 2010). Once the structural layout is determined, the annual output can be estimated to within approximately $3 \%$ using the average monthly solar radiation and average monthly day-time temperature (Huld et al., 2010; Perpinan et al., 2008).

\section{Methods}

\subsection{Lot Area Estimation 1: Parking Lot and Impervious Surface}

The step in developing and evaluating the scenario of widespread PV parking canopy development is to ascertain exactly how much land area is available. Our area estimation made use of data freely available from the Massachusetts Office of Geographic Information (MassGIS) and ESRI's ArcGIS Desktop software. The data were the MBTA parking lot in point form (MassGIS, 2006) and the impervious surface (MassGIS, 2007) layers. The MBTA parking lot layer, as provided to MassGIS by the Executive Office of Transportation, includes many attributes such as facility type and number of parking spaces. The impervious surface layer was derived from the 2005 Color Ortho Imagery project by the Sanborn Map Company and includes all forms of cement, brick, asphalt, and packed dirt visible at one meter resolution. MBTA parking lots are assumed to have a compact shape, such as a square, as opposed to a line. As such, the points were buffered with a radius one-half that of the number of spaces for all types of facilities, except that of garages. As garages are multi-story complexes, one-tenth of the number of spaces was used as a radius for the buffer to decrease the inclusion of surrounding structures in the area estimate. The buffered parking lots were then converted to raster and overlaid on the impervious surface layer and the area of all impervious surface cells that lie within these buffered regions were summed in meters. This methodology assumes there is relatively little to no pervious surface (such as grass or tree islands) within the bounds of the parking lot and, simultaneously, that any given parking lot is surrounded by some pervious surface.

MassGIS (2009) freely distributes very high resolution (15-30 cm) areal imagery of Boston and the surrounding area which is used by Google in its Google Earth and Maps products. We use this data to perform an accuracy assessment of our GIS modeled parking areas by exporting the MBTA parking lot data from ESRI's ArcGIS 
format to Google Earth. First, the points where checked to determine whether they were in the approximate center of each parking lot. Then six individual lots were randomly chosen from the garage lots and nine lots were selected from the remaining non-garage lots. Polygons of all 15 lots were drawn and exported back to ArcGIS format, which calculates the area covered by each polygon. The resulting areas were assumed to be the most accurate estimates and were used to perform an accuracy assessment for both area estimations performed in this study.

\subsection{Lot Area Estimation 2: Google Earth and Single Space Averages}

According to the Victoria Transportation Policy Institute (2010), the average space (including access lanes) in an off-street parking lot in the US requires between 27.9 and 32.5 square meters. To test whether this held true for some sample lots in Boston, polygons of three parking lots near Boston University's Campus were again drawn in Google Earth and exported to ArcGIS. The number of parking spaces was counted for each test parking lot and individual space requirements averaged accordingly. Polygons of the 15 full parking lots were again used to perform an accuracy assessment of the area estimation.

\subsection{PV System Area Requirements}

As previously discussed, shading of panels can substantially reduce output. Therefore an important consideration in determining the land area required by any PV installation is limiting or excluding the effect of shadows (Alonso-Garcia et al., 2006; Perpinan et al., 2008). Without knowledge of the texture of the areas surrounding the parking lots, only shadows created by the PV modules could be considered. However, this is consistent with the location of most MBTA parking areas which are generally away from large buildings and thus we believe it does not introduce undue error in our area estimates. Assuming that the PV modules will be installed on a fixed structure and tilted south to a degree equal that of its location's latitude, simple geometry can be used to calculate the area required by any one PV module (as shown in Figure 1). We assume PV panel dimensions that are representative of modules from other such studies (Huld et al., 2010; Perpinan et al., 2008; Ayompe et al., 2010).

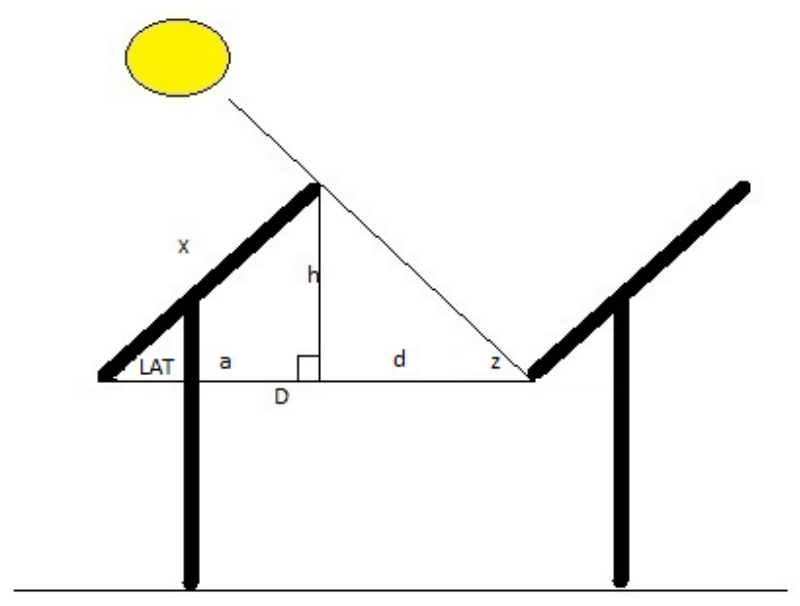

Figure 1. Shadow effects of one array on another

$$
\begin{gathered}
h=X * \operatorname{SIN}(L A T) \\
a=X * \operatorname{COS}(L A T) \\
d=\frac{h}{\operatorname{TAN}(z)} \\
D=a+d \\
A_{\text {mod }}=P V_{w} * D
\end{gathered}
$$


Equations 1-5 (above) calculate the horizontal area required by a PV module $\left(A_{\bmod }\right)$ where $X$ is the module length, $L A T$ is the latitude, $z$ is the sun's angle (90-zenith), $P V_{w}$ is the module width, and $D$ is the distance from the south (low) edge of one module to the south edge of the next module either directly north or south (NREL, 1990). Precise latitude was the only parameter that varied and is specific to each parking lot. The zenith angle (65 degrees) was chosen because it approximates the lowest the sun gets in Boston over the course of a year. Using the calculated area required by one PV module, we are then able to estimate the number of modules possible in a given installation.

\subsection{Electricity Production and Installation Costs}

Electricity production potential is calculated using straightforward mathematical relationships that take as inputs the average global radiation (from NREL, 2010), installed module surface area, rated power output per module, average temperature (from NREL, 2010), inverter and wiring efficiencies, and module degradation rate (from Ayompe, 2010). As for the module dimensions, the rated power output per module was chosen based on reviewed studies (Ayompe, 2010; Huld et al., 2010). The power production equations (Eq. 6-10) were adapted from Huld et al. (2010) and are defined as follows (see Table 1 for variable definitions):

$$
\begin{gathered}
P\left(G^{\prime}, T^{\prime}\right)=P_{s t c} * G^{\prime} * N_{r e l}\left(G^{\prime}, T^{\prime}\right) \\
N_{\text {rel }}\left(G^{\prime}, T^{\prime}\right)=1+k_{1} l n G^{\prime}+k_{2} \ln \left(G^{\prime}\right)^{2}+T^{\prime}\left(k_{3}+k_{4} \ln G^{\prime}+k_{5} \ln \left(G^{\prime}\right)^{2}\right)+k_{6}\left(T^{\prime}\right)^{2} \\
G^{\prime}=\frac{G}{1000} \\
T^{\prime}=T_{\text {mod }}-T_{\text {mod_stc }} \\
T_{\text {mod }}=T_{\text {amb }}+c T * G
\end{gathered}
$$

To convert the resulting output from direct current to active current) the inverter and wiring efficiencies were multiplied to approximate the DC to AC conversion efficiency of the system. The present value of electricity was determined by applying the degradation rate to all future years' production over the lifetime of the PV modules, and multiplying by the price of electricity. Installation costs are based on the peak wattage of a given system and are tracked and reported by industry on the Solar Buzz website (Note 1). The remainder of the installation cost is the BOS cost. To calculate the net present cost of an installation two costs remain: the BOS replacement cost and the variable costs. The limiting component of the BOS is the inverter, which typically only has a lifespan of 10 years (Ayompe et al., 2010). The present value of the electricity produced is calculated by multiplying the average annual electricity production by the cost of electricity. The future benefits and costs were discounted to represent the time value of money before the net present value was calculated by subtracting the costs from the revenue. The precise discount rate for policy decision making (and whether a discount rate should be used at all) is a matter of some debate (Note 2), however we employ the commonly used rate of 0.05 over the lifetime of the installation (Ayompe et al., 2010). Finally we use the energy output and the EIA figures for emissions from electricity generation in Massachusetts (EIA, 2012) to estimate avoided emissions of carbon dioxide, nitrogen oxide, and sulfur dioxide. Table 1 (below) lists the parameters and variables used in this study (Note 3). 
Table 1. Study parameters

\begin{tabular}{|c|c|c|c|}
\hline Name & abbreviation & value & units \\
\hline MBTA parking lot layer (MassGIS, 2006) & N/A & $\mathrm{N} / \mathrm{A}$ & N/A \\
\hline Impervious surface layer (MassGIS, 2007) & N/A & N/A & N/A \\
\hline Horizontal area per module & $\mathrm{A}_{\text {mod }}$ & varies & $\mathrm{m}^{2}$ \\
\hline Latitude (MassGIS, 2006) & LAT & varies & DD \\
\hline Zenith angle (NREL, 2010) & zenith & 65 & degrees \\
\hline Power output at standard testing conditions & $\mathrm{P}_{\text {stc }}$ & 200 & $\mathrm{~W}$ \\
\hline Average daily irradiance (NREL, 2010) & $\mathrm{G}$ & varies & $\mathrm{W} / \mathrm{m}^{2}$ \\
\hline Average daily temperature (NREL, 2010) & $\mathrm{T}_{\mathrm{amb}}$ & varies & deg. F \\
\hline Normalized irradiance & $\mathrm{G}^{\prime}$ & varies & N/A \\
\hline Normalized temperature & $\mathrm{T}^{\prime}$ & varies & N/A \\
\hline Module temperature & $\mathrm{T}_{\text {mod }}$ & varies & deg. F \\
\hline Module temperature at standard temperature and pressure & $\mathrm{T}_{\text {mod stc }}$ & varies & deg. F \\
\hline Relative efficiency & $\mathrm{N}_{\text {rel }}$ & varies & N/A \\
\hline \multirow[t]{7}{*}{ Coefficients (Huld et al., 2010) } & $\mathrm{cT}$ & 0.035 & N/A \\
\hline & $\mathrm{k} 1$ & -0.01716 & N/A \\
\hline & $\mathrm{k} 2$ & -0.04029 & N/A \\
\hline & $\mathrm{k} 3$ & -0.00468 & N/A \\
\hline & $\mathrm{k} 4$ & 0.000148 & N/A \\
\hline & $\mathrm{k} 5$ & 0.000169 & N/A \\
\hline & k6 & 0.000005 & N/A \\
\hline Inverter efficiency (Ayompe, 2010) & I & 0.935 & N/A \\
\hline Wiring efficiency (Ayompe, 2010) & $\mathrm{W}$ & 0.9 & N/A \\
\hline PV module lifetime (Ayompe, 2010) & $\mathrm{L}$ & 25 & Years \\
\hline degradation rate (Ayompe, 2010) & $\mathrm{D}$ & 0.0082 & $\mathrm{~N} / \mathrm{A}$ \\
\hline Module Cost (Solarbuzz) & $\mathrm{Cm}$ & 4.21 & $\$ / W p$ \\
\hline BOS cost factor (Ayompe, 2010) & BOSc & 0.54 & N/A \\
\hline BOS replacement factor (Ayompe, 2010) & $\mathrm{BOSr}$ & 0.7 & N/A \\
\hline Variable cost factor (Ayompe, 2010) & $\mathrm{Vc}$ & 0.01 & N/A \\
\hline Discount Rate (Ayompe, 2010) & $\mathrm{R}$ & 0.05 & N/A \\
\hline Price of Electricity (EIA, 2012) & $\mathrm{Pe}^{-}$ & 0.1484 & $\$ / \mathrm{kWh}$ \\
\hline Price of Electricity increase rate(Ayompe, 2010) & $\mathrm{Pe}_{\mathrm{r}}^{-}$ & 0.045 & N/A \\
\hline CO2 emission intensity (EIA, 2012) & $\mathrm{CO} 2$ & 1154 & $\mathrm{lbs} / \mathrm{MWh}$ \\
\hline NO emission intensity (EIA, 2012) & NO & 1 & $\mathrm{lb} / \mathrm{MWh}$ \\
\hline SO2 emission intensity (EIA, 2012) & $\mathrm{SO} 2$ & 2.3 & $\mathrm{lbs} / \mathrm{MWh}$ \\
\hline
\end{tabular}

\section{Results}

\subsection{Lot Area Estimations and Accuracy Assessments}

The first area estimation (Figure 2), point buffer was found to be inaccurate. For the 15 sample parking lots, the average area was $20,783 \mathrm{~m}^{2}$ with a standard deviation of $23,002 \mathrm{~m}^{2}$. As the parking lots are not expected to be of equal size, these raw values simply show that there is a large variation in the area estimates. The zonal sum method, on average, overestimates the parking lot area by $150 \%$ of the actual size, if each area estimate is compared to the actual area (as defined by the estimate made using ground truth combined with orthophotos and Google Earth). However, when parking lot type is considered, it becomes apparent that the zonal sum method performed much better. On average the zonal sum method overestimated parking garage areas by only $14 \%$, whereas the same approach overestimated ground level parking lots by $248 \%$ or 3.48 times the actual area. 


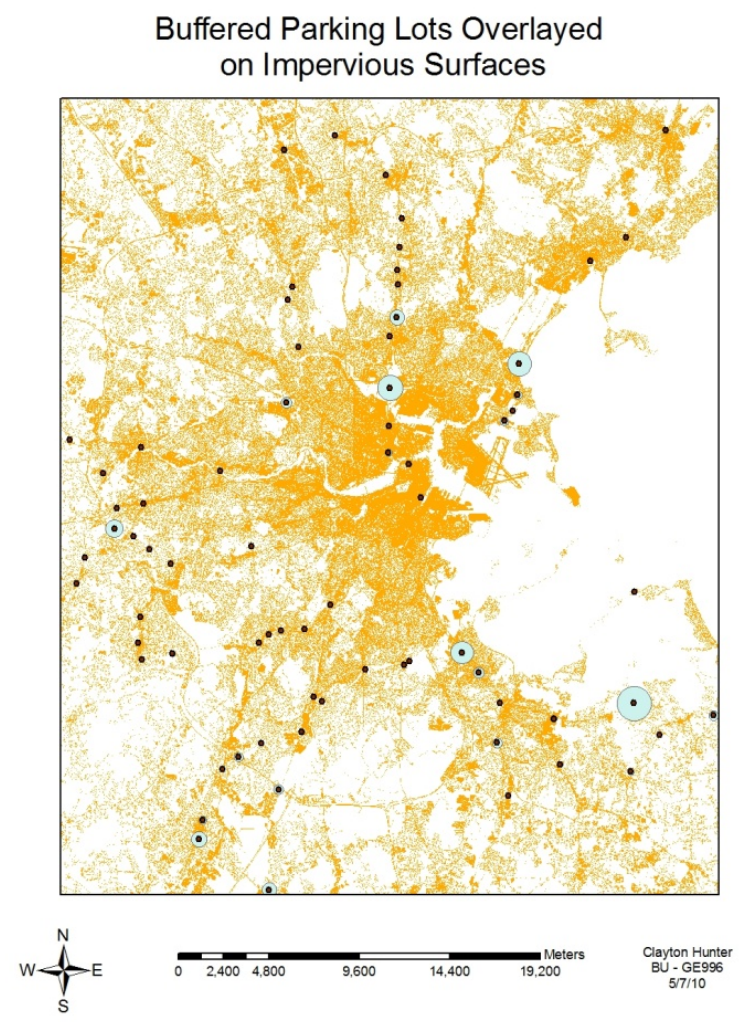

Figure 2. Points are MBTA parking lots, light blue circles seen around some lots are buffered regions, and both are overlayed on the impervious surface layer. The center of the image is the city of Boston

The second area estimation approach, which simply multiplied the number of parking spaces by the average single space area $\left(31.5 \mathrm{~m}^{2}\right)$, returned an average lot size of $12,765 \mathrm{~m}^{2}$ with a standard deviation of $12,657 \mathrm{~m}^{2} . \mathrm{By}$ again normalizing the values to those measured in Google Earth, the average lot was overestimated by $111 \%$ and performed better on the ground level lots than the parking garages. This single space method overestimated average garage areas by $222 \%$, but only overestimated ground lots by an average of $37 \%$. Figure 3 (below) shows the difference in estimated areas by the two different approaches as well as the ground truth as measured using Google Earth.

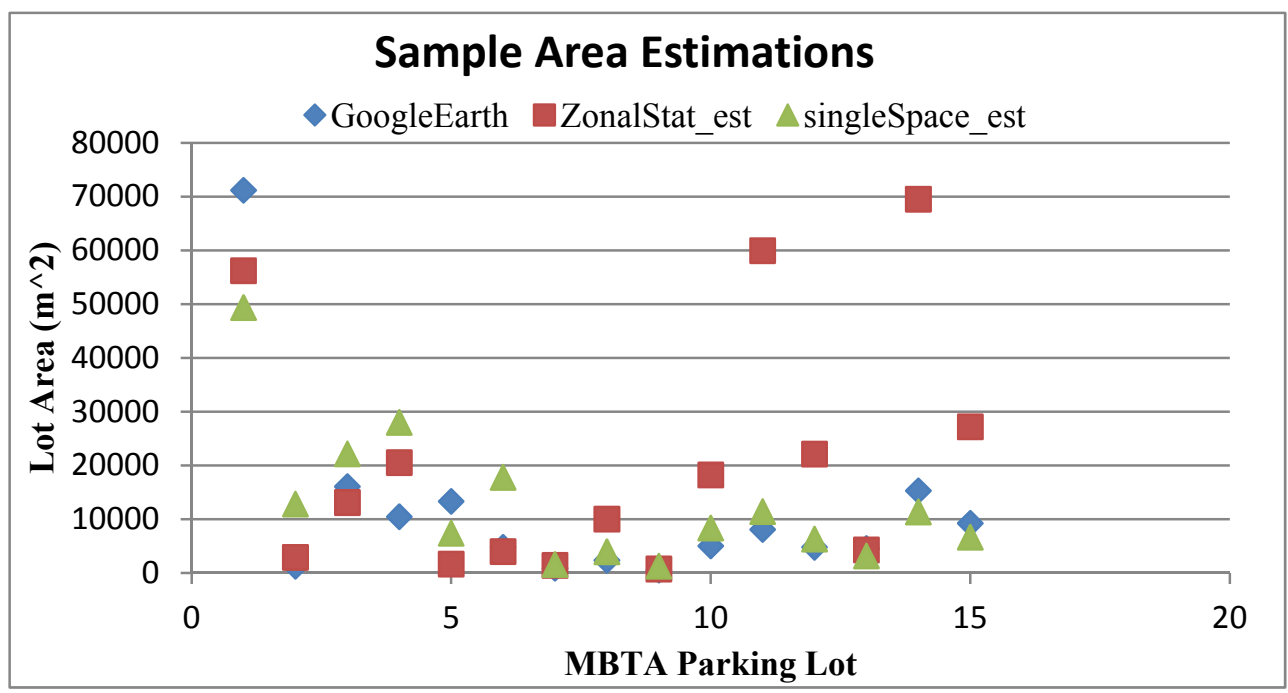

Figure 3. Sample area estimation as measured in Google Earth and as calculated using two approaches 
The first six records correspond to parking garages and the remainder to off-street, ground level lots. Especially notable are lots $8-15$, where, except for two closely approximated examples, the zonal sum method (depicted by red squares) can be seen to greatly overestimate ground level lots and the same lot areas are strongly correlated with the actual areas. Based upon the observed performance of each technique previously described, the available area for each parking garage was defined by the zonal sum method and for each ground level lot by the single space method.

\subsection{PV System Area, Electricity Production, and Net Present Value}

The average required area per module was calculated as $1.8996 \mathrm{~m}^{2}$ with a standard deviation of $0.0027 \mathrm{~m}^{2}$. The average electricity production (active current) for the first year was found to be $742.4 \mathrm{kWh}$ with a total of 102.4 MWh. At that production level, the electricity produced by PV canopies over the 138 MBTA parking lots would produce approximately $0.013 \%$ of electricity demand in Massachusetts. Over 25 years, the total electricity production would equal approximately $2.3 \mathrm{GWh}$. Interestingly, as seen in table 2 (below), the total monthly power output peaks in March rather than in the middle of summer when there is the highest sun exposure. This is attributable to the decline in performance with higher temperatures that occurs with PV panels.

Table 2. Monthly power production for the first year $(\mathrm{kWh})$

\begin{tabular}{ccccccc}
\hline & January & February & March & April & May & June \\
\hline Total: & 7097.54 & 8235.51 & 10069.03 & 9723.96 & 9470.70 & 8577.43 \\
Average: & 51.43 & 59.68 & 72.96 & 70.46 & 68.63 & 62.16 \\
\hline & July & August & September & October & November & December \\
\hline Total: & 8687.27 & 9086.46 & 9169.23 & 9002.80 & 6978.89 & 6349.55 \\
Average: & 62.95 & 65.84 & 66.44 & 65.23 & 50.57 & 46.01 \\
\hline
\end{tabular}

To calculate the net present value (NPV) of any installation, the net present costs and benefits must be determined. At a peak output of 191.4 MW, the PV modules are estimated to cost 805.9 million USD (M\$) and the BOS components just under $435.2 \mathrm{M} \$$, which would put the initial installation costs at $1.2 \mathrm{~B} \$$. The future BOS replacement and annual variable costs are estimated at $56 \mathrm{M} \$$ and $174.9 \mathrm{M} \$$, respectively. This means that the net present cost of installing PV canopies at all 138 MBTA parking lots would equal 1.46 billion (2008\$).

At the modeled production level of $102.4 \mathrm{MWh}$ in the first year and a price of $0.1484 \$ / \mathrm{kWh}$, revenue from the first year would equal $\$ 15,203$. Accounting for future increases in electricity prices as well as degradation rates of the panels using the values from Table 1, the net present revenue is equal to $15.4 \mathrm{M} \$$. Thus the total NPV is $-1.46 \mathrm{~B} \$$ and the average NPV for an individual installation is $-10.6 \mathrm{M} \$$ in our modeled scenario. The average installation has a net present benefit of $10.56 \mathrm{M} \$$.

Table 3. Summary of net present costs, revenue, and value

\begin{tabular}{cccc}
\hline & Net Costs $(\mathrm{M} \$)$ & Net Revenue (M\$) & NPV (M\$) \\
\hline Total: & 1472 & 1.60 & $-1,456$ \\
Average: & 10.70 & 0.12 & -10.60 \\
\hline
\end{tabular}

These numbers do not provide a strong case for PV canopy development, however they represent only the direct market value of such a project. Knowledge of the external costs and benefits is critical information needed for planning and public decision making. Among the potential positive externalities of renewable energy projects are the offset of critical air pollutants such as sulfur and nitrogen oxides as well as the savings with respect to carbon emissions and offset climate change potential. Additionally, distributed redundancy in energy systems provides resiliency to a critical and vulnerable infrastructure. Identifying a precise dollar value for these benefits is beyond the scope of this project, however we are able to provide a quantitative measure of the emissions abatement that would result from our PV canopy scenario. Using the figures on electricity production related emissions from the EIA we are able to calculate the annual emissions avoidances for $\mathrm{CO}_{2}, \mathrm{NO}$ and $\mathrm{SO}_{2}$ resulting from the offset in fossil fuel combustion. These values are seen in table 4 with both the total emissions avoided and the individual installation average avoided emissions. 
Table 4. Emissions avoided in first year

\begin{tabular}{llll}
\hline & $\mathrm{CO}_{2}$ (tonnes) & $\mathrm{NO}(\mathrm{kg})$ & $\mathrm{SO}_{2}(\mathrm{~kg})$ \\
\hline Total: & 53.73 & 46.57 & 107.10 \\
Average Site: & 0.38 & 0.34 & 0.78 \\
\hline
\end{tabular}

In a location that is classified as a "non-attainment area" by the U.S. EPA with respect to the National Ambient Air-Quality Standards (Note 4), these avoided emissions are an important and valuable benefit of renewable energy development. If we assume that the excess net present cost of the project (anything less than a breakeven NPV of zero) is to be offset by the benefit of avoided emissions we can estimate the per pound cost of the offsets over the 25 year life of the installations. The degradation of the panels in that time equates to an average output for the panels of approximately $90 \%$ of the first year output. We use this output level to determine the lifetime present cost per pound of abated emissions which is equal to the negative net present value divided by the sum of average lifetime emissions (Table 5). It is quite apparent that under current conditions in NPV terms this is an expensive emissions abatement scheme.

Table 5. Present value cost of avoided emissions over the 25 year lifetime of the project

\begin{tabular}{cccc}
\hline & $\mathrm{CO}_{2}$ & $\mathrm{NO}$ & $\mathrm{SO}_{2}$ \\
\hline Total Emissions Avoided(kg): & $1,209,123.45$ & $1,047.82$ & $2,409.75$ \\
US\$/lbs & 1,204 & 1.39 million & 0.60 million \\
\hline
\end{tabular}

\section{Conclusions}

Increased attention and action aimed at addressing climate change through the reduction of greenhouse gas emissions has brought ever more focus on renewable energy technologies. This work developed a scenario of large scale distributed photovoltaic energy production making use of existing publicly managed land in a large metropolitan area where Massachusetts Bay Transit Authority parking areas. We evaluated the economic viability of such a scenario using net present value analysis and quantify the associated emissions offset that this scenario would entail. We find a generation potential equal to $102.4 \mathrm{MWh}$ or $0.013 \%$ of electricity consumption in Massachusetts and annual emissions offsets equal to 53.7 tonnes of $\mathrm{CO}_{2}, 46.5 \mathrm{~kg}$ of NO , and $107.1 \mathrm{~kg} \mathrm{of} \mathrm{SO}_{2}$. However the market conditions for such a scenario are not favorable with a calculated NPV of -1.4 billion U.S. dollars for the project.

Our results demonstrate two key points. Urban environments have great potential for generating renewable energy supplies while offsetting the emissions associated with conventional energy production. Secondly that such a scenario is not economically viable under current market conditions in urban areas with low solar potential. For the scenario to be a financially viable solution for energy production in Massachusetts, several fundamental conditions must be changed. Through the evolution of the market or through policy intervention, the cost of PV systems decrease or the value of avoided pollution must increase. Examples of such conditions include creative financing that pushes payment into the discounted future (for example see Singh and Singh, 2010), energy pricing that favors low carbon production, a decline in panel costs or advances in technology, or the use of more generous social discount rates. Both the costs and efficiency of PV panels have been steadily improving in recent years and the other options are readily manipulated via policy makers. It is our hope that this paper highlights both the potential for creative integration of distributed renewable energy production, and the challenges that remain for their implementation.

\section{References}

Alonso-Garcia, M. C., Ruiz, J. M., \& Chenlo, F. (2006). Experimental study of mismatch and shading effects in the I-V characteristic of a photovoltaic module. Solar Energy Materials and Solar Cells, 90(3), 329-340. http://dx.doi.org/10.1016/j.solmat.2005.04.022

Ayompe, L. M., Duffy, A., McCormack, S. J., \& Conlon, M. (2010). Projected costs of a grid-connected domestic PV system under different scenarios in Ireland, using measured data from a trial installation. Energy Policy, 38(7), 3731-3743. http://dx.doi.org/10.1016/j.enpol.2010.02.051

Bergmann, A., Colombo, S., \& Hanley, N. (2008). Rural versus urban preferences for renewable energy developments. Ecological Economics, 65(3), 616-625. http://dx.doi.org/10.1016/j.ecolecon.2007.08.011 
Caplin, A., \& Leahy, J. (2004). The Social Discount Rate. Journal of Political Economy, 112(6), 1257-1268. http://www.jstor.org/stable/10.1086/424740

Davis, A. Y., Pijanowski, B. C., Robinson, K., \& Engel, B. (2010). The environmental and economic costs of sprawling parking lots in the United States. Land Use Policy, 27(2), 255-261. http://dx.doi.org/10.1016/j.landusepol.2009.03.002

Denholm, P., \& Margolis, R. (2006). Very Large-Scale Deployment of Grid-Connected Solar Photovoltaics in the United States: Challenges and Opportunities. NREL/CP-620-39683. Retrieved from http://www.nrel.gov/docs/fy06osti/39683.pdf

El-Sebaii, A. A., Al-Hazmi, F. S., Al-Ghamdi, A. A., \& Yaghmour, S. J. (2010). Global, direct and diffuse solar radiation on horizontal and tilted surfaces in Jeddah, Saudi Arabia. Applied Energy, 87(2), 568-576. http://dx.doi.org/10.1016/j.apenergy.2009.06.032

Energy Information Administration (EIA). (2012) Official Energy Statistics from the U.S. Government. Retrieved from http://www.eia.doe.gov/

Golden, J. S., Carlson, J., Kaloush, K. E., \& Phelan, P. (2007). A comparative study of the thermal and radiative impacts of photovoltaic canopies on pavement surface temperatures. Solar Energy, 81(7), 872-883. http://dx.doi.org/10.1016/j.solener.2006.11.007

Huld, T., Gottshalg, R., Beyer, H. G., \& Topic, M. (2010). Mapping the performance of PV modules, effects of module type and data averaging. Solar Energy, 84(2), 324-338. http://dx.doi.org/10.1016/j.solener.2009.12.002

Intergovernmental Panel on Climate Change (IPCC). (2007). IPCC Fourth Assessment Report: Climate Change 2007. Retrieved from http://www.ipcc.ch/publications_and_data/publications_and_data_reports.htm\#1

Jannson, P. M., \& Michelfelder, R. A. (2008). Integrating Renewables into the U.S. Grid: Is It Sustainable? The Electricity Journal, 21(6), 9-21. http://dx.doi.org/10.1016/j.tej.2008.07.005

Jun, E., Kim, W. J., Jeong, Y. H., \& Chang, S. H. (2010). Measuring the social value of nuclear energy using

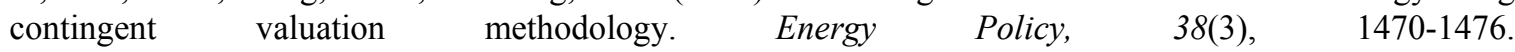
http://dx.doi.org/10.1016/j.enpol.2009.11.028

Knepper, V. (2007). Developing parking policies to support smart growth in local jurisdictions: best practices. Metropolitan Transportation Commission for San Francisco Bay Area, CA. Retrieved from http://www.mtc.ca.gov/planning/smart_growth/parking_seminar/BestPractices.pdf

Li, H., Jenkins-Smith, H. C., Silva, C. L., Berrens, R. P., \& Herron, K. G. (2009). Public support for reducing US reliance on fossil fuels: Investigating household willingness-to-pay for energy research and development. Ecological Economics, 68(3), 731-742. http://dx.doi.org/10.1016/j.ecolecon.2008.06.005

Mandalaki, M., Zervas, K., Tsoutsos, T., \& Vazakas, A. (2012). Assessment of fixed shading devices with integrated PV for efficient energy use. Solar Energy, 86(9), 2561-2575. http://dx.doi.org/10.1016/j.solener.2012.05.026

Massachusetts Clean Energy Center (MCEC). (2012). Massachusetts Residential Guide to Solar Power. Retrieved from http://www.masscec.com/index.cfm/pk/download/id/13301/pid/11163

Massachusetts Office of Geographic Information (MassGIS). (2006). MBTA Parking Lots. Retrieved from http://www.mass.gov/mgis/eot_layers.htm

Massachusetts Office of Geographic Information (MassGIS). (2007). Impervious Surface. Retrieved from http://www.mass.gov/mgis/impervious_surface.htm

Massachusetts Office of Geographic Information (MassGIS). (2009). USGS Color Ortho Imagery 2008/2009. Retrieved from http://www.mass.gov/mgis/colororthos2008.htm

McPherson, E. G. (2009). Sacramento's parking lot shading ordinance: environmental and economic costs of $\begin{array}{lllll}\text { compliance. Landscape and Urban } & \text { 105-123. }\end{array}$ http://dx.doi.org/10.1016/S0169-2046(01)00196-7

Menegaki, A. (2008). Valuation for renewable energy: A comparative review. Renewable and Sustainable Energy Reviews, 12(9), 2422-2437. http://dx.doi.org/10.1016/j.rser.2007.06.003 
Moore, M. A., Boardman, A. E., Vining, A. R., Weimer, D. L., \& Greenberg, D. H. (2004). "Just give me a number!” Practical values for the social discount rate. Journal of Policy Analysis and Management, 23(4), 789-812.

Mousazadeh, H., Keyhani, A., Arzhang, J., Mobli, H. Abrinia, K., \& Sharifi, A. (2009). A review of principle and sun-tracking methods for maximizing solar systems output. Renewable and Sustainable Energy Reviews, 13(8), 1800-1818. http://dx.doi.org/10.1016/j.rser.2009.01.022

Noguera, J. (2005), Parking lots, store chains and spatial agglomeration. Papers in Regional Science, 84(2), 145-158. http://dx.doi.org/10.1111/j.1435-5957.2005.00010.x

Perpinan, O., Lorenzo, E., Castro, M. A., \& Eyras, R. (2008). On the complexity of radiation models for PV $\begin{array}{lllll}\text { energy production } & \text { calculation. } & \text { Solar } & \text { Energy, } & \text { 82(2), }\end{array}$ http://dx.doi.org/10.1016/j.solener.2007.06.007

Rambaud, S. C., \& Torrecillas, M. J. M. (2005). Some considerations on the social discount rate. Environmental Science \& Policy, 8(4), 343-355. http://dx.doi.org/10.1016/j.envsci.2005.04.003

Singh, P. P., \& Singh, S. (2010). Realistic generation cost of solar photovoltaic electricity. Renewable Energy, 35(3), 563-569. http://dx.doi.org/10.1016/j.renene.2009.07.020

Sovacool, B. (2009). The intermittency of wind, solar, and renewable electricity generators: Technical barrier or rhetorical excuse? Utilities Policy, 17(3-4), 288-296. http://dx.doi.org/10.1016/j.jup.2008.07.001

U.S. National Renewable Energy Lab (NREL). (1990). National Solar Radiation Data Base User's Manual (1961-1990). Retrieved from http://rredc.nrel.gov/solar/old_data/nsrdb/

Victoria Transportation Policy Institute. (2010). 5.4 Parking. Transportation Cost and Benefit Analysis II Parking Costs. Retrieved from http://www.vtpi.org/tca/tca0504.pdf

\section{Notes}

Note 1. www.Solarbuzz.com is published by the NPD Group, Port Washington, NY, USA, data available from http://www.solarbuzz.com/Moduleprices.htm

Note 2. See variously Moore et al., 2004; Caplin and Leahy, 2004 and Rambaud and Torrecillas among many other works on the topic.

Note 3. For consistency all values are for 2008.

Note 4. Current attainment and non-attainment areas as well as the criteria pollution levels are available via the U.S. Environmental Protection Agency website, www.epa.gov 